\title{
High chloride, sulphate and fluoride concentrations in clay-rich aquitard porewater, the North China Plain: evidence of geochemical behavior
}

\author{
Dongmei $\mathrm{Han}^{1, *}$, Guoliang $\mathrm{Cao}^{2}$, and Andrew J. Love ${ }^{3}$ \\ ${ }^{1}$ Key Laboratory of Water Cycle \& Related Land Surface Processes, Institute of Geographic Sciences \\ and Natural Resources Research, Chinese Academy of Sciences, Beijing, 100101, China \\ ${ }^{2}$ State Key Laboratory of Simulation and Regulation of Water Cycle in River Basin, China Institute of \\ Water Resources and Hydropower Research, Beijing 100038, China \\ ${ }^{3}$ National Centre for Groundwater Research \& Training, Flinders University, Adelaide, SA 5001, \\ Australia
}

\begin{abstract}
The focus of this investigation was to constrain the porewater chemistry from tracer and ion profiles in a $128 \mathrm{~m}$ thick clay-rich sequence of Quaternary sediments comprising the clay, silt and fine sand formation in the North China Plain. Porewater are much more saline (1.1-71.0 g/L) than the lower confined groundwaters $(0.3-1.3 \mathrm{~g} / \mathrm{L})$. Chloride profiles from aqueous extraction (AE) (ranging from 117 to $3260 \mathrm{mg} / \mathrm{L}$ ) generally keep good consistent with that obtained from squeezing test (ST). However, the sulphate and fluoride concentrations by AE (ranging from 340 to 48,700 $\mathrm{mg} / \mathrm{L}$ and from 8.8 to $144 \mathrm{mg} / \mathrm{L}$, respectively) are far greater than that by ST. Dissolution of evaporites may be responsible for the high $\mathrm{Cl} / \mathrm{Br}$ ratios greater than 1000 , probably indicating recharge occurred during much wetter periods. The original stable isotopic and chemical compositions in the aquitard porewater have been modified by transpiration and evaporation processes concentrating $\mathrm{Cl}$ and causing isotopic enrichment during their formation periods. Dissolution of fluorite, hieratite, and cryolite caused by weathering behavior and ion-exchange reactions should be responsible for the high fluoride concentrations in the aquitard porewater. High sulphate levels found in aqueous samples may arise from pyrite oxidation during sampling, storage and/or porewater extraction procedure.
\end{abstract}

\section{Introduction}

Aquitards can play a profound role on groundwater flow and solute transport in adjacent aquifers. The current understanding of clay-rich aquitard systems, and especially the poor knowledge concerning the geochemical processes that are important in the solutes transport in these deposits, lags far behind our understanding of the behavior of solutes in aquifer

\footnotetext{
*Corresponding author: handm@igsnrr.ac.cn
} 
systems. At present, the aquitards in the south Saskatchewan area of Canada have received the highest degree of research, and almost all of the related issues have been done there by Jim Hendry and his team members in the past 30 years [1-4]. In Europe, the CLAYTRAC Project has been implemented in France, Belgium, Germany, UK, Denmark and Australia. The aquitards include clay/shale/shaly siltstone, the largest thickness of shaly siltstone investigated can reach $404 \mathrm{~m}$. In Australia, the related research focused on Great Artesian Basin and Murry Darling Basin. In recent years, there are five locations for conducting aquitard studies in China. They are mainly distributed in North China Plain, Subei Plain, and Pearl River Delta. One deepest borehole with $1100 \mathrm{~m}$ was drilled at Tianjin. The main research aspects for understanding the complex physical and chemical behavior of clay-rich aquitard systems, include multi-environmental tracers and hydraulic data; residence times, transport mechanisms, (bio)geochemical processes, and origin of porewater and solutes in an aquitard system; chemical heterogeneity in diffusion-dominated aquitards; timing of major climatic and geologic events; estimating geotechnical/hydraulic properties.

\section{Study area}

The North China Plain (NCP) is located in northeastern China (Fig. 1). Currently, groundwater has provided $\sim 70 \%$ of the total water supply to support agricultural irrigation in the NCP. It can be divided into three major zones: 1. Piedmont Plain; 2. Central plain; 3. Coastal plain. The Quaternary sediments are composed of four main aquifer units, which are separated by aquitards. From 1975 to 2000 in Hengshui City, due to the groundwater over-exploitation, the declining groundwater level in deep aquifer was far greater than that in shallow aquifer. Shallow saline groundwater is distributed in most of the central and coastal plain. The area of the shallow saline water occupies $\sim 60 \%$ of the whole plain.

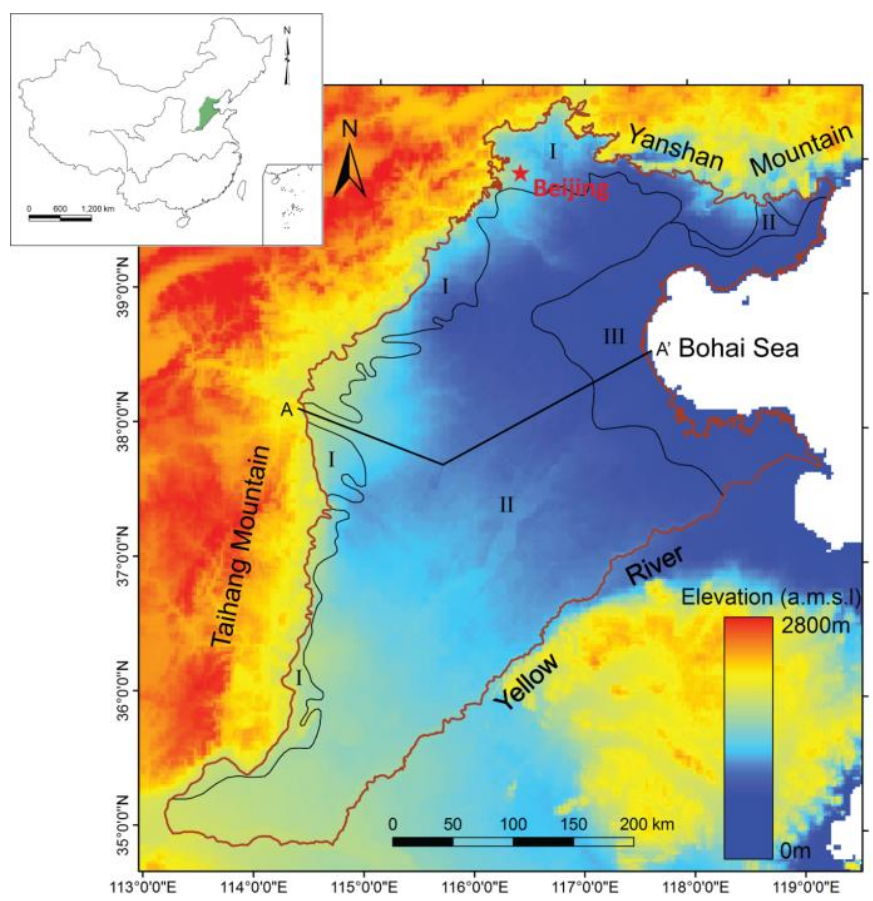

Fig. 1. Location map of the North China Plain

I- Piadmont plain, II-Central plain, III-Coastal plain. 
The main research questions and motivation include: What are the controlling processes for modifying aquitard pore water chemistry? To determine the factors responsible for the salinized trend observed in deep fresh aquifers, and to improve understanding time-scale of porewater transport in aquitard systems by reconstructing paleohydrogeological conditions.

\section{Sampling and analysis}

Clay-rich aquitards occur extensively in the central and coastal plain. We conducted core sampling and logging campaigns in the Hengshui site for monitoring water levels and porewater extraction, and chemical and stable isotopic analysis. Fig. 2a shows the stratigraphic column of the sampling borehole. Samples of rock core were obtained from different intervals from this borehole. Fig. $2 \mathrm{~b}$ displays samples processing and analysis. 110 pore water samples from clay-rich rock core were obtained by applying aqueous extraction.
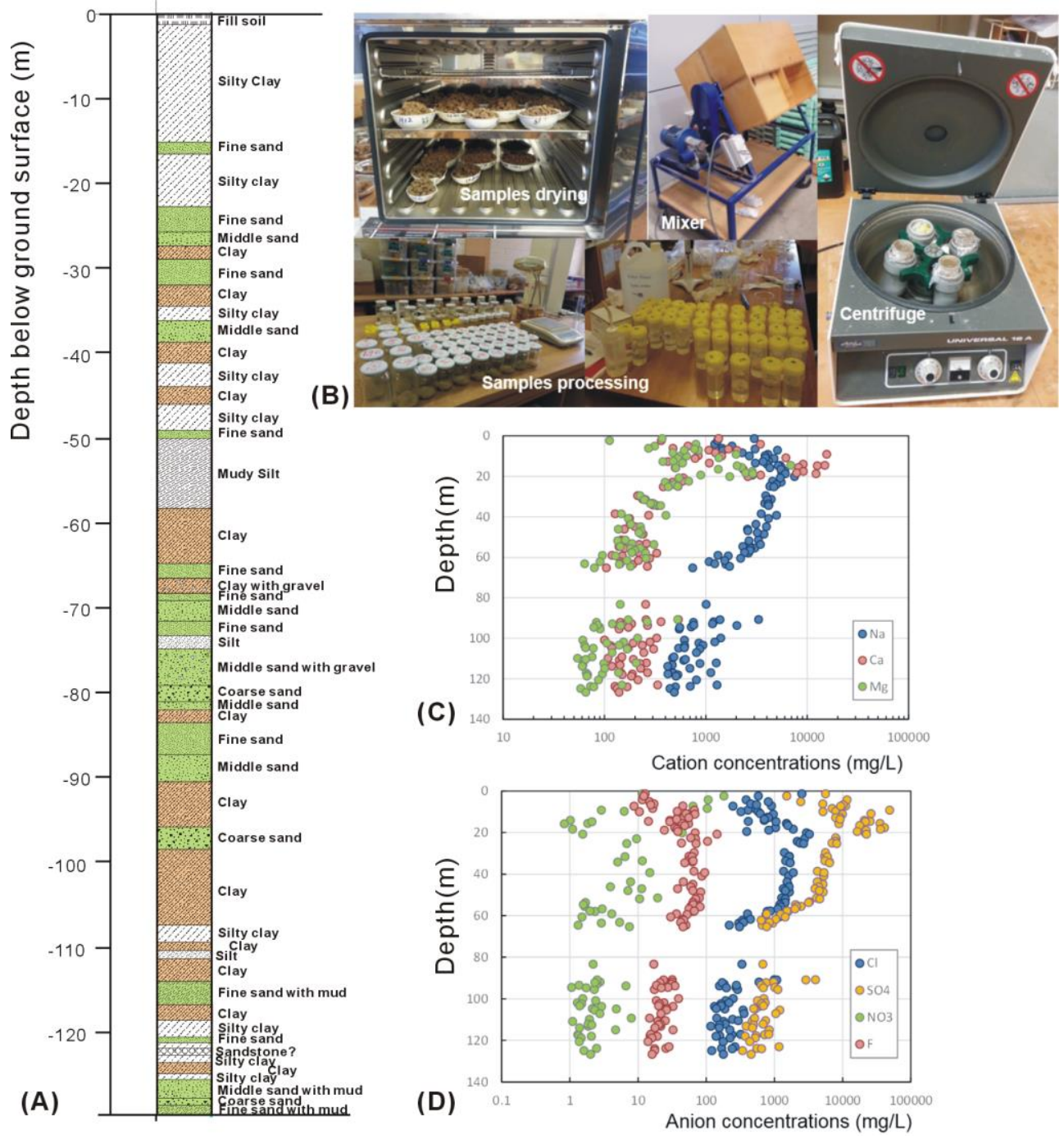

Fig. 2. a- the stratigraphic column of the drilled borehole; b- Aquaous extraction process; c- cationdepth profile, and d- anion-depth profile for showing porewater chemistry. 


\section{Results and discussion}

Pore waters in the aquitard are classified as sodium sulfate chloride-type waters. The $\mathrm{Na}^{+}$ and $\mathrm{K}^{+}, \mathrm{Mg}^{2+}$, and $\mathrm{SO}_{4}{ }^{2-}$ concentrations yielded very similar depth profiles (Figs. $2 \mathrm{c}$ and $2 \mathrm{~d})$. The elevated concentrations of chloride and other dissolved ions can be similarly observed at about $20-\mathrm{m}$ depth. Porewater are much more saline $(1.1 \sim 71.0 \mathrm{~g} / \mathrm{L})$ than the lower confined groundwaters $(0.3 \sim 1.3 \mathrm{~g} / \mathrm{L})$. In order to exclude the machine error, the pretreated water samples were measured in two labs of our institute (Beijing) and Flinders University. It can be confirmed from almost the same results that high sulfate $(0.3-48.7 \mathrm{~g} / \mathrm{L}$ with mean $6.1 \mathrm{~g} / \mathrm{L}$ ) concentrations in the porewater. It has been reported that there are high sulphate concentrations in clay porewater in North Mexico [5] and Belgium [6].

Distribution of rare earth elements in groundwater or porewater can be used to identify geochemical behaviors or conditions. Cerium anomaly can be regarded as a potential tracer for redox conditions. Large positive Ce anomalies in the central and coastal plain result from reductive dissolution of $\mathrm{Fe} / \mathrm{Mn}$ oxides/oxyhydroxides in moderate anaerobic conditions. The synchronous increase of Fe and Mn contents (Fig. 3) would still have to be interpretated as due to the reductive dissolution of soil Fe and Mn oxyhydroxides; or a mechanism based on the reductive desorption of organic compounds. Additionally, the fresh core samples are in dark gray color indicate the unoxidized conditions.

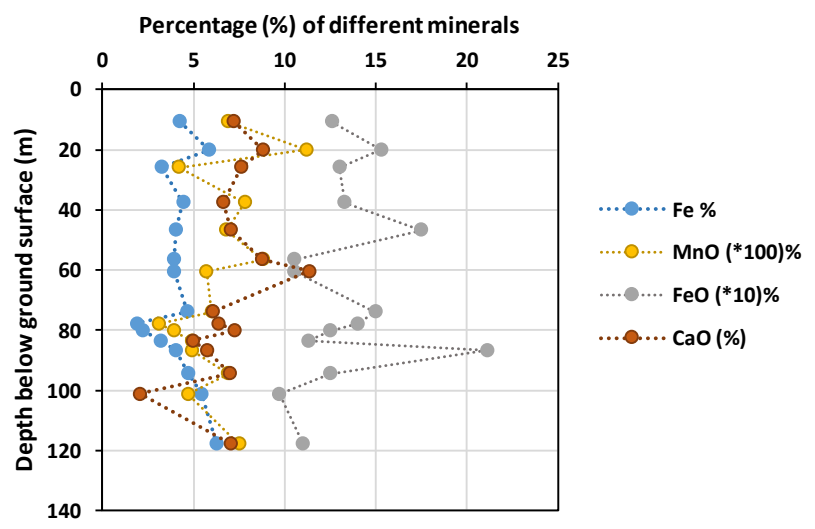

Fig 3. Results of XRD analysis for the core samples.

However, pyrite, which is offen found in the sediments of the North China Plain [7], is generally the main sulphur-bearing phase in argillaceous rocks. High sulphate levels found in aqueous extracts and squeezed samples may arise from pyrite oxidation during sampling, storage and/or porewater extraction procedure $[8,9]$, which were reported by Wersin and others [10].

The elevated fluoride concentrations in aquitard porewater may be explained by the following aspects. Firstly, dissolution of fluorite $\left(\mathrm{CaF}_{2}\right)$, Hieratite $\left(\mathrm{K}_{2} \mathrm{SiF}_{6}\right)$, and Cryolite $\left(\mathrm{Na}_{3} \mathrm{AlF}_{6}\right)$ caused by weathering rocks, e.g. tuff, gneiss, schist, limestone. Secondly, the increase in calcium concentration by the dissolution of calcite will subsequently trigger ion exchange reactions. High content of calcium will be exchanged onto clay which releases sodium, potassium, and magnesium into aqueous phase. Indeed, the ion exchange mechanism can satisfactorily explain the observed increase of $\mathrm{Na}, \mathrm{K}$, and $\mathrm{Mg}$ concentrations up to a sulphate concentration of thousands ppm. This process can enhance $\mathrm{pH}$ values.

There is the wide scatter on the plot (Fig. 4) of $\mathrm{Cl} / \mathrm{Br}$ ratios versus $\mathrm{Cl}$ concentrations of aquitard porewater, indicating that bromide is not behaving conservatively. Dissolution of evaporites can be responsible for the high ratios greater than 1000, probably indicating recharge occurred during much wetter periods. To compare the ratios of groundwater with that of porewater, these plots may 
reflect that water-rock interaction could be responsible for the higher ratios. The oceanic source is not clear even for the coastal groundwater. There is a weak hydrodynamic connection between the investigated porewater and the groundwater in the central plain.

Fig. 4. $\mathrm{Cl} / \mathrm{Br}$ ratio versus chloride for aquitard porewater.

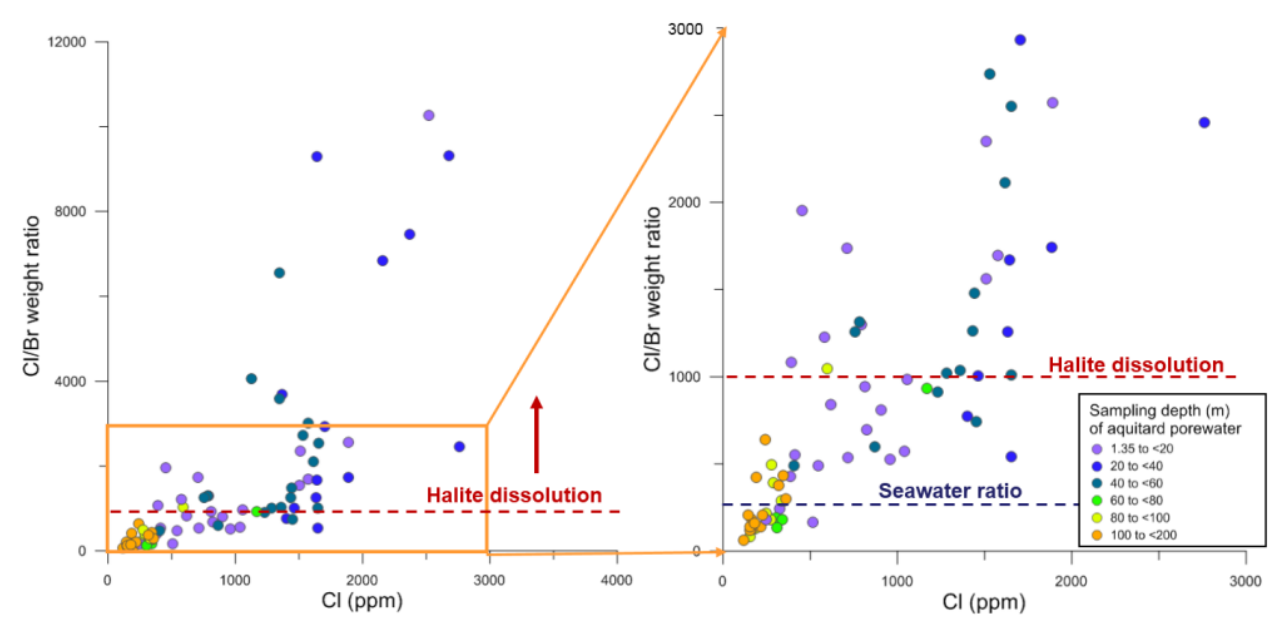

The greater isotopic enrichments of shallow groundwater indicate a period of relatively humid and warm climate in the Holocene [11]. Compared with the stable isotopic compositions of groundwater, it can be inferred that the deeper aquitard porewater $(>60 \mathrm{~m})$ could be recharged during the late Pleistocene. The process mixing the regional groundwater with the trapped connate seawater via diffusion is unlikely due to these data have a meteoric signal obviouly different from that of seawater. It also indicates that there is weak interaction between deep fresh groundwater and aquitard porewater (depth $>50 \mathrm{~m}$ ). Fig. 5 reflects that the original stable isotopic and chemical compositions have been modified by transpiration processes concentrating $\mathrm{Cl}$, and evaporation causing isotopic enrichment during their formation periods. The trend for the shallow aquitard $(<20 \mathrm{~m}$ depth) shown in Fig. 5 may be caused by the effects of transpiration, while the complete evaporation of rainfall and subsequent dissolution of minerals during the wet period with recharge events may be responsible for the trend of the deeper porewaters.

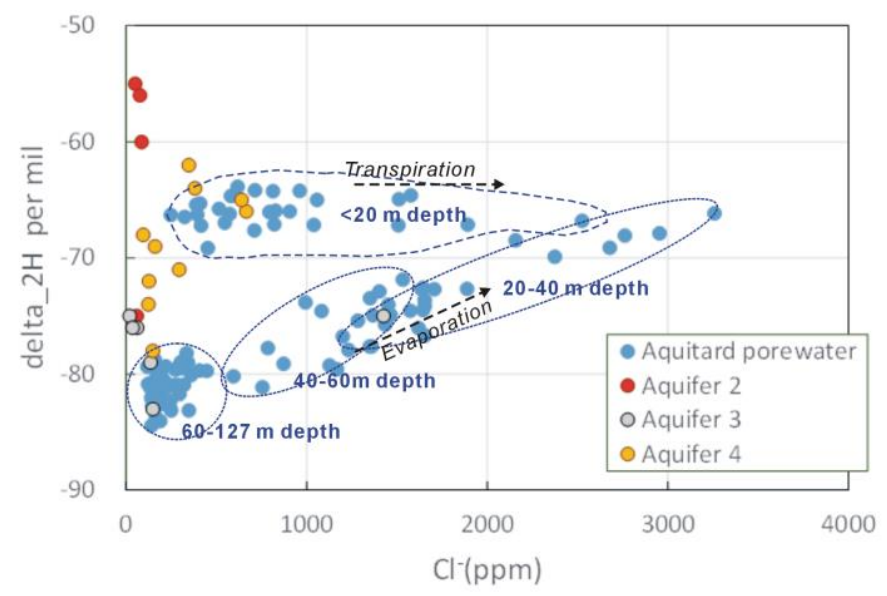

Fig. 5. Plot of $\mathrm{Cl}^{-}$conc. versus $\delta^{2} \mathrm{H}$ values with comparison between porewater and groundwater. 


\section{Conclusions}

Currently, downward hydrodynamic gradient of groundwater caused by the present pumping conditions does not change the original distribution of hydrochemistry of aquitard porewater. The variations of $\mathrm{Cl} / \mathrm{Br}$ ratios versus $\mathrm{Cl}$ concentrations of aquitard porewater indicates that bromide is not behaving conservatively. Dissolution of evaporites may be responsible for the high $\mathrm{Cl} / \mathrm{Br}$ ratios greater than 1000 , probably indicating recharge occurred during much wetter periods. The greater isotopes enrichments of shallow groundwater indicate a period of relatively humid and warm climate in the Holocene. Aquitard porewater (depth $>40 \mathrm{~m}$ ) in inland Hengshui profile have had all tracers of connate water and salts mainly controlled by evaporation since the late Pleistocene (i.e. $\sim 1 \mathrm{Ma} \mathrm{BP}$ ). Based on the relationship between deuterium and oxygen isotope data, we can find that the process mixing the regional groundwater with the trapped connate seawater via diffusion is unlikely as these data have a meteoric signature pronouncedly different from that of seawater. We observed fluorite in the cores by XRD analysis. Dissolution of fluorite caused by weathering behavior and ion-exchange reactions should be responsible for the high fluoride concentrations in the aquitard porewater. High sulphate levels found in aqueous samples may arise from pyrite oxidation during sampling, storage and/or porewater extraction procedure, not occurs in porewater under unoxidized condition.

Acknowledgements. This research was financially supported by the National Natural Science Foundation of China (No. 41371057) ), and also funded by the Youth Innovation Promotion Association, Chinese Academy Sciences (No. 2012040).

\section{References}

1. M. J. Hendry, Hydrology of clay till in a prairie region of Canada, Ground Water. 26, (1988)

2. M. J. Hendry, L.I.Wassenaar, 1999. Wat. Resour. Res., 35(6) (1999)

3. G.A. Harrington, M. J. Hendry, Robinson N.I., Wat. Res. Res., 43 (2007)

4. M. J. Hendry, S.L. Barbour, K. Novakowski, L.I. Wassenaar, Wat. Res. Res., 49 (2013)

5. M. J. Hendry, S.L. Barbour, E.E. Schmeling, S.O.C. Mundle, M. Huang, Wat. Resour. Res. 52 (2016)

6. A. Ortega-Guerrero, J. Hydrol. 284 (2003)

7. M. De Craen, M.Van Geet, L.Wang, M. Put, Phys. Chem. Earth. 29 (2004)

8. Li X., Zhou A., Gan Y., Yu T., Wang D., Liu Y., Jour. of Hydrol., 400 (2011)

9. M. De Craen, I. Wemaere, S. Labat, M. Van Geet, SCK.CEN External Report CENER-19. Available at http://publications.sckcen.be. (2006)

10. E.C.Gaucher, C.Tournassat, F.J. Pearson, P. Blanc, C. Crouzet, C. Lerouge, S. Altmann, Geochim. Cosmochim. Ac. 73 (2009)

11. P. Wersin, M. Mazurek, U.K. Mäder, T. Gimmi, D. Rufer, C. Lerouge, D. Traber, Chem. Geol. 434 (2016)

12. Z. Chen, J. Qi, J. Xu, J.Xu, H.Ye, Y. Nan, Appl. Geochem. 18 (2003) 